\title{
Spies, Lies, and a Commission: A Case Study in the Mobilization of the Canadian Civil Liberties Movement ${ }^{1}$
}

\section{Dominique Clément}

\begin{abstract}
It was unnecessary to set up a Royal Commission to do a police job, and a job that had already been done by the R.C.M.P. There is no Canadian precedent and no authority for setting up of a Royal Commission to sit in secret. There does not seem to be any authority for the action of the Commission in swearing witnesses to secrecy. The Commission refused to advise witnesses as to their rights, even when requested to do so. In many cases the Commission refused access to counsel at a time when the Commissioners well know that charges would be preferred against the person asking counsel. The Commissioners showed strong political bias and prejudice, and by the procedure they adopted they unfairly handicapped the defence of the accused. ${ }^{2}$
\end{abstract}

This remonstrance was part of a letter sent to Justice Minister J.L. Ilsley by the Civil Rights Union (Toronto) in February, 1947, and emphasizes what civil libertarians found most abhorrent about the Royal Commission on Espionage. The commission, from February to August, 1946, embarked on one of the most thorough abuses of individual rights ever conducted by an organ of the Canadian state. ${ }^{3}$ It was armed with extensive powers under the War Measures Act, Official Secrets Act and the Public Inquiries Act to determine the extent of the Soviet spy ring in Canada revealed by the defection of Igor Gouzenko. ${ }^{4}$ Coming on the heels of the deportation of Japanese Canadians in 1945-6 and extensive censorship under the Defence of Canada Regulations throughout World War Two (WWII), the commission provided civil libertarians with another powerful issue to remind the public of the vulnerability of individual's civil liberties to state abuse..$^{5}$

The Royal Commission on Espionage played a key role in stimulating the early civil liberties movement in post-WWII Canada. An analysis of the debates surrounding the commission's investigation will reveal that an organized civil liberties movement existed in Canada by 1946. The emergence of a reinvigorated civil liberties movement manifested itself in the form of new civil liberties organizations and widespread criticisms in the press of the government's abuses. The movement, however, was far from united. It was ideologically divided between communists and social democrats. Parliamentary critics of the commission's abuse of individual rights and their demands for reform crossed party lines. But the voices were few. Although no major reforms to protect civil liberties would emerge from the events of 1946-8, a stronger, 
better organized and more vocal civil liberties movement emerged as a result. It would go on to lobby for legislation which would provide greater protection for individual freedoms and increase public awareness about the need for change. This article will discuss the nature of the civil liberties movement in post-WWII Canada and the role played by the Royal Commission on Espionage in its development.

On 5 September, 1945 Igor Gouzenko, a cipher clerk in the Soviet embassy in Ottawa, defected and sought asylum in Canada. The night Gouzenko defected, he stashed under his coat a series of documents that proved the existence of an espionage ring operated by the Soviets within Canada. Among the sixteen people incriminated by these documents was a member of the Bank of Canada (Eric Adams), an employee in the British High Commissioner's office (Kathleen Willisher), a Member of Parliament (Fred Rose), and a member of the cipher division in the Prime Minister's own ministry, External Affairs (Emma Woikin). Gouzenko soon came to the attention of Prime Minister Mackenzie King and Norman Robertson. After the initial shock wore off and King had decided to grant Gouzenko asylum, concerns arose as to the implications of making the defection public. In his diary, King described how he and Robertson had "agreed that great caution must be used from now on in the matter of avoiding any kind of publicity, hoping that matters can be straightened out without the public ever becoming aware of what had taken place." King was especially worried about the effect that revelations of a defection and spy ring would have on the upcoming meeting of the Council of Foreign Ministers in which the Soviet Union was meeting with its wartime allies to discuss everything from the Greek civil war to the atom bomb. In consultation with three other cabinet ministers (Louis St. Laurent, minister of justice, Norman Robertson, senior bureaucrat in external affairs, and C.D. Howe, minister of munitions and supply), King passed order-in-council PC 6444 on 6 October, 1945. It was thus in total secrecy that four members of the cabinet empowered the Minister of Justice to circumvent centuries of traditional British liberties to investigate Gouzenko's allegations.

PC 6444 was passed under the authority of the War Measures Act. The order-in-council stipulated that "it is deemed necessary for the security, defence, peace, order and welfare of Canada that the Acting Prime Minister or the Minister of Justice should be authorized to order the detention of such persons in such places and under such conditions as [they] may from time to time determine." The order further allowed that individuals "detained by virtue of an order made under this Order, be deemed in legal custody." 8 The effect of PC 6444 was to suspend habeas corpus and allow the government to detain individuals suspected of espionage for as long as the Minister of Justice or Acting Prime Minister desired. No judge in Canada or Britain had the authority to release a person detained under this order and the Minister was not required to explain or justify the detention of a suspect to anyone.

The Minister of Justice and the Royal Canadian Mounted Police (RCMP) began their investigation by thoroughly interrogating Gouzenko at a small 
military training facility outside Toronto called "Camp X." They were initially hesitant to take advantage of the sweeping powers provided by PC 6444 and there is no evidence in King's diaries that he ever intended to go public about the defection. By February, 1946, King likely assumed that Gouzenko would disappear into obscurity.

King's hand was forced on 4 February, 1946 when an American radio personality, Drew Pearson, announced that he had discovered information about a Russian defector in Canada with evidence on hundreds of Soviet spies operating throughout North America. How Pearson knew about the defection has been a question of debate by several historians, but King immediately suspected the American's (possibly President Harry Truman or FBI Director J. Edgar Hoover) of leaking the story to Pearson to force King to begin making arrests. ${ }^{10}$ The next day, King called his cabinet together and passed another order-in-council, PC 411, to create a Royal Commission that would investigate Gouzenko's allegations. The commission was to be led by Supreme Court justices Roy Lindsay Kellock and Robert Taschereau with E.K. Williams, President of the Canadian Bar Association (CBA), as chief legal counsel.

Gouzenko's defection, PC 6444 and the commission would remain secret for another ten days as the commission established itself and debriefed Gouzenko. On 15 February, 1946 RCMP officers in plain clothes stormed the homes of thirteen suspected spies and interned them at the Rockliffe military barracks in Ottawa. In a press release, King was vague, mentioning only that a defection had taken place and that individuals were suspected of passing on secret information to a foreign government. ${ }^{11}$

What followed was one of the most extensive abuses of civil liberties ever engaged in by the Canadian state. Each detainee was held in isolation with twenty-four hour lighting and under suicide watch by an RCMP guard who was told not to communicate with the prisoners. ${ }^{12}$ The suspects were held incommunicado, without access to family, friends or legal counsel. At first, the prisoners were "prepped" by RCMP lead investigator, C.W. Harvison, who encouraged them to cooperate with the commissioners. ${ }^{13}$ Each suspect was then brought before the commission and questioned about their activities and relationships with other suspects. If they refused to cooperate, suspects were warned that they were being legally detained by the government and that refusal to testify could result in a charge of contempt of court leading to six months in jail. They were also told that no one had charged them with a crime and that the commission was simply conducting an investigation. ${ }^{14}$ With no access to legal counsel and under intense psychological strain, it is not surprising that several prisoners broke down and confessed. ${ }^{15}$

Refusal to allow suspects to retain and instruct a lawyer was a prosecutorial discretion permitted by the Public Inquiries Act which is responsible for defining the parameters of a Royal Commission. The Public Inquiries Act of 1906 empowers a commission to "summon before them any witnesses, and of 
requiring them to give evidence on oath... and to compel them to give evidence as is vested in any court of record in civil cases." ${ }^{16}$ In a 1912 revision, the Act further stated that "the commissioners may allow any person whose conduct is being investigated under this Act... to be represented by counsel." 17 The commission was therefore able to hold suspects for an indeterminate length of time, incommunicado, without access to legal counsel and empowered to compel them to testify under the threat of being cited for contempt of court. Testimony gleaned during these proceedings was then used in court to convict several of the suspects. Had the suspects been allowed access to legal counsel, it is probable that their lawyer would have insisted they be given protection under the Canada Evidence Act against self-incrimination. ${ }^{18}$ By refusing the suspects' access to a lawyer, there was a greater likelyhood of convicting them. That this was the government's intention is supported by a secret memo to Mackenzie King dated 5 December, 1945, in which E.K. Williams warned that "criminal proceedings at this stage are not advisable. No prosecution with the evidence now available could succeed except one of Back, Badeau, Nora, and Grey." ${ }^{19} \mathrm{He}$ believed the state would be unable to convict the spies if the government proceeded with a police investigation. Williams recommended a Royal Commission because "it need not be bound by the ordinary rules of evidence if it considers it desirable to disregard them. It need not permit counsel to appear for those to be interrogated by or before it." 20

The commission submitted its final report on 27 June, 1946. ${ }^{21}$ Since 5 February, 1946, the commission had released three interim reports (4 March, 14 March and 29 March). Each report was followed by the release of several detainees; for some, the ordeal lasted only a couple of weeks while, for others, it lasted up to five weeks at Rockliffe barracks. A report prepared by the Ottawa Civil Liberties Association described the condition of the suspects following their release. Kathleen Willisher "seemed confused and unaware of her surroundings. Her clothes were good but her black seal coat looked as if she had slept in it. There were deep black rings under her eyes and deep lines in her face... She swayed as she stood bent over, her head down."22 A description of Gordon Lunan's (a captain in the Canadian army) first appearance in court has him standing "rigidly at attention, every muscle taunt, as the charge was read." 23 Edward Mazerall, a scientist with the National Research Council, was described as "haggard." The observer was "reminded of pictures I have seen of people rescued from German concentration camps. [Mazeral1] said nothing and his lawyer asked for a remand."24 In a final commentary on the court proceedings from the first group of prisoners released from the barracks, one witness suggested the following:

I wasn't able to forget their faces or the strange way they behaved as they were being charged. Surely it must be instinctive for people to want to defend themselves. They weren't being convicted. Nothing had been 
proved against them. I may not know what a spy looks like or how he acts, but I do know something about human beings. Why didn't they particularly the two women - ask for help? Counsel had been offered to them and they had refused even this elementary right. What had been happening to them during the 18 days when they had seen no one but police? What have these people been through to make them behave in this way? No one knows but themselves, and they haven't the opportunity to tell. 25

Of the sixteen people eventually charged for violating or attempting to violate the Official Secrets Act, six were convicted, primarily on their testimony before the commission and Gouzenko's testimony in court ${ }^{26}$ All of the suspects, however, were found guilty by the commission. Royal Commissions do not have the power to convict people of a crime, yet in each case the final report accused sixteen people of communicating secret information to the Soviets and for violating the Official Secrets Act. ${ }^{27}$ For some, jobs were lost while others' reputations were tarnished, despite having been acquitted in a court of law. Following his trial (in which he was acquitted), Israel Halperin was reinstated as a professor of mathematics at Queen's University. Soon after his appointment there was a great deal of pressure on the Principal of the university to fire him. The Board of Trustees were aware that Halperin was acquitted because certain evidence was not admitted in court and they had read in the commission's report that Halperin was a communist and guilty of violating the Official Secrets Act. In the end, after much debate, his job was barely saved through the influence of Chancellor Charles Dunning who feared possible embarrassment to the school. ${ }^{28}$

The final "spy trial" resulting from the commission's investigation was that of Sam Carr, a party organizer for the Labour Progressive Party, who was convicted on 9 April, 1949 and sentenced to six years in prison. ${ }^{29}$ Carr and Fred Rose, the two lead organizers of the spy ring, received the longest sentences of six years each. Seven other suspects were convicted and received between three and five years in prison; the remaining nine people accused by the commission of violating the Official Secrets Act were either not charged for lack of evidence or acquitted in court. ${ }^{30}$

The historiography on the events of 1946-9 is surprisingly limited. The Gouzenko Affair has attracted a great deal of commentary from historians over the past fifty years, but few have examined the Royal Commission on Espionage in detail and no published work has yet to provide anything more than a cursory examination of the early civil liberties movement. Reg Whitaker and Gary Marcuse offer the most extensive analysis of the commission presently available in their recent work, Cold War Canada: The Making of a National Insecurity State, 1945-1957.31 In reference to the civil liberties movement and the Gouzenko Affair, Marcuse and Whitaker suggest that, 


\section{Left History 7.2}

An organized civil libertarian response was mounted, but it was largely directed either by people associated with the communist party or by independent socialists to the left of the CCF. In 1946 there was no Canadian Civil Liberties Association in existence, but there were civilliberties groups that had been organized during the war in some of the major cities. Little was heard from these in the Gouzenko affair; instead, a new, communist-dominated group [Civil Rights Union] carried the ball

- with quite predictable results given its political affiliation. ${ }^{32}$

Larry Hannant also provides a brief overview of the post-WWII civil liberties movement within the context of RCMP security screening in his book, The Infernal Machine: Investigating the Loyalty of Canada's Citizens. His examination is limited to one chapter, but it remains the only detailed description on the early Canadian civil liberties movement in print. Hannant does not discuss the impact of the Royal Commission on Espionage on the early civil liberties movement, but instead contends that,

Gouzenko's... impact upon security screening has not been widely recognized... Yet no one has acknowledged him to be the unlikely instigator of a civil liberties' breakthrough in Canada. Certainly, his defection gave the Canadian state the opportunity officially to set up a screening system for civil servants. But, in doing so, the Canadian state was forced to make a profound admission. When the cabinet issued Directive 4 on security screening in 1948 it formally recognized for the first time the existence of a functioning vetting system."33

Both works emphasize two important, yet separate, aspects of the early civil liberties movement. Whitaker and Marcuse point out the ideological divisions that plagued organized civil liberties groups while Hannant argues the significance of the events of 1946-8 for increasing public awareness. Unfortunately, both works only deal with these issues peripherally. As the following examination will demonstrate, Marcuse and Whitaker are too quick in dismissing the reaction from civil libertarians to the commission's exploits. Despite the divisions inherent in the movement, civil libertarians were able to react quickly and decisively in condemning the government's use of a royal commission with extensive powers to investigate a spy ring.

In a system of Parliamentary supremacy in which there are no constitutionally entrenched protections for individual rights, the ability to stimulate public awareness in order to promote the need for legislative change is crucial to an effective civil liberties campaign. The press became increasingly critical of the government's tactics following the publication of the first interim report on 2 March 1946, which revealed that David Shugar and eight other suspects remained interned in the Rockliffe barracks. With the realization that the government continued to hold nine people without access to family and 
counsel, the press quickly focussed on the possible breach of the suspects' rights. A study of six English daily papers (Evening Citizen, Halifax Herald, Montreal Gazette, Winnipeg Free Press, Globe and Mail and the Vancouver Sun) and two French dailies (Le Devoir and Action Catholique) reveals a divided reaction amongst the press to the commission's tactics.

The editor of the Winnipeg Free Press, George Ferguson, was particularly disgusted by the commission but conceded that the government was forced to act under extreme circumstances. Despite his sympathy with the government's situation, however, Ferguson contended that people disliked the thought of citizens held incommunicado, even if they represented a threat to the state. ${ }^{34} \mathrm{He}$ suggested that, as a result of the commission's extraordinary tactics, the press had become more concerned with the commission's actions than with the crime itself. This became more pronounced after the second interim report when it was revealed that the commission continued to hold five people who had been neither charged nor given access to counsel for over a month. ${ }^{35}$ As a writer for Saturday Night proposed, "public interest, which should have been vividly focussed on a single point, was diverted from the central drama and led off in another direction, so that while half the audience was attempting to follow the spy narrative, the other half was trying to track down the civil rights of the suspect." 36

Harold Pritchett, a member of the Vancouver Civil Liberties Union and of the Communist Party of Canada, voiced his concerns over PC 6444 in an article for the Vancouver Sun. He argued that "it [PC 6444] is more offensive to the Canadian sense of justice than is necessary, and is a greater potential source of evil than its creators likely considered." 37

Even the normally conservative Globe and Mail felt the government had overreached its authority. In reaction to the commission's first interim report, A.A. McIntosh wrote in an editorial:

Here the suspects have been imprisoned without charge, held incommunicado for long periods pending their examination, under extreme powers of the War Measures Act and its peacetime substitution the National Emergency Transition Powers Act... It might be argued that without the secrecy preserved in Ottawa there would have been no discovery of all who may be involved. Of itself, so important an objective does not excuse the adoption of so vicious an instrument [commission]... All rules of freedom, the basic liberties of the individual, must, we all know, be subordinate on occasion to the safety of the state. But there is nothing in the acceptance of this which licenses the Government to suspend all the judicial safeguards in order to facilitate police work or make easier the conduct of an official inquiry. ${ }^{38}$

Not every editor perceived the commission's actions as an unnecessary violation of individual rights. The editor of the Montreal Gazette wrote that "the 
fact that we were so co-operative to let these persons into our confidence is no reason why we should be so cooperative as to aid them in concealing their tracks. As it is, the investigation will not be easy for us, we should not, by untimely constitutional pedantry, make it easy for those we pursue." 39 The editor of the Halifax Herald similarly believed that the circumstances of the case justified the commission's methods, and no less than thirteen editorials appeared between February and April in the Halifax Herald criticizing members of the press for raising the issue of civil liberties. ${ }^{40}$

Between 16 February, 1946 and 16 April, 1946, press coverage of the commission and the spy trials was extensive. An analysis of six English language newspapers suggests that each paper carried a story on the commission almost every day between 16 February, and 16 April. ${ }^{41} \mathrm{~A}$ significant percentage of these stories appeared on the front page of the newspaper (on average, thirtysix out of forty-seven newspapers printed during this time period featured a headline on the espionage affair). The issue of the suspects' civil liberties was a common theme, particularly after 2 March 1946 when the commission released its first interim report. Articles included interviews by family members attempting to contact the suspects interned in the Rockliffe barracks, statements by lawyers who could not speak with their clients, and failed attempts by relatives of Matt Nightingale and Fred Poland to ask the courts to issue writs of habeas corpus to force the commission to release its detainees.

Individual commentary was no less numerous. All six English papers printed between 10-15 different editorials on the espionage affair within a twomonth period. While editors for the Montreal Gazette and Halifax Herald were quick to support the government's actions, editors for the Winnipeg Free Press, Vancouver Sun, Evening Citizen and the Globe and Mail were critical of the commission's extreme tactics. Of the forty-seven papers published between 16 February, and 16 April, by each paper, an average of eight different editorials specifically discussed the issue of civil liberties. In contrast, the espionage affair received limited attention in the French-language papers. Le Devoir provided some coverage of the commission and the spy trials, but only fifteen of fortyseven papers carried headlines, and the question of the suspects' individual rights was rarely mentioned. For another popular French language newspaper, Action Catholique, the espionage affair and the civil liberties abuses were a nonissue. The only story that dealt with the commission was an editorial that pointed to the defections as an example of French-Canadian moral superiority (all of the suspects were anglophones). ${ }^{42}$

In the House of Commons, which convened in March 1946, debate over the use of a royal commission to investigate Gouzenko's claims crossed party lines. Chubby Power, a backbencher from Montreal, declared before the House that "I cannot by my silence appear to approve even tacitly what I believe to have been a great mistake on the part of the government. If this is to be the funeral of Liberalism I do not wish by not taking part in this debate to give silent approval 
of the procedure which has taken place." 43 Power followed up his position by resigning from the Liberal party in a show of opposition to the government's support of the commission. A Liberal Senator, Arthur Roebuck, was publicly critical of the commission. Roebuck had been a founder of the Ottawa Civil Liberties Association. He was quoted in the Toronto Star as accusing the commissioners of having "walked over civil rights of accused persons as no experienced police officer would dream of doing, and they did things which no good crown attorney would for one moment permit." 44 He later stated before a civil rights rally in 1947 that the "civil rights of six persons [suspects acquitted in court] have been flagrantly and cruelly invaded and so too were those of the eight found guilty, and what disturbs me is the fact that those responsible for the procedure... have not disavowed their error, but rather do they defend it." 45

Members of the Conservative party, including party leader John Bracken as well as John Diefenbaker and Davie Fulton, joined the attack on the government's use of a Royal Commission. Diefenbaker and Fulton brought the debate to the House committee responsible for drafting a new Citizenship Act; at one point, Diefenbaker motioned for an amendment to the proposed Act that would have added a short Bill of Rights to protect against similar abuses of individual rights in the future. ${ }^{46}$ Members of the Co-Operative Commonwealth Federation (CCF), including party leader M.J. Coldwell, joined the chorus of criticism of the King government in the House and on the citizenship committee. Coldwell and Alistair Stewart perceived the commission as an attempt to deviate from traditional legal practices while surrounded by unnecessary secrecy ${ }^{47}$ Stanley Knowles brought the issue up again in 1947 when Parliament was debating the creation of a joint committee of the House and Senate to study the plausibility of a Canadian Bill of Rights (Joint Committee on Human Rights and Fundamental Freedoms). He read letters from the Manitoba Civil Liberties Association (of which he was a member) to the House calling for a Bill of Rights to be enshrined in the constitution to avoid excessive abuse of individual rights by the executive. ${ }^{48}$ Only the Social Credit Party's leader openly supported the government's actions in his opening speech and dismissed concerns over civil liberties abuses. ${ }^{49}$

Throughout the debates of 1946 and renewed again in 1947 during the debate over the Joint Committee on the Bill of the Rights, King and his cabinet continued to defend their actions and the commission. Louis St. Laurent, Minister of Justice, in May 1946 justified the creation of a royal commission empowered under the War Measures Act as necessary in order to deal with a crisis situation. At one point, St. Laurent claimed that, "in this royal commission the purpose was not to pronounce upon the innocence or guilt of any of ten or thirteen or more persons but to find out to what extent the security of this state had been endangered by a conspiracy to set up this fifth column in this country." ${ }^{50}$ In the following year, when criticisms of the royal commission and demands for a Bill of Rights arose once again in the House of Commons, J.L. 
Ilsley, the new Minister of Justice, took St. Laurent's position in defending the government's actions. During the 1947 debates, several Liberals also opposed the creation of a Bill of Rights, particularly MP's from Quebec who were concerned about incursions into provincial jurisdiction. ${ }^{51}$ Others, such as Ian Mackenzie, argued that "many of the rights and privileges which we prize highly we do not owe to specific statutes. Rather we owe them to the absence of laws which would prohibit them." 52

It is clear that, at the very least, the commission played a key role in increasing debate in the public arena over the vulnerability of Canadians' individual rights from state abuse. In May 1946, a poll conducted by the Toronto Star determined that $93 \%$ of respondents had heard about the Gouzenko Affair and $61 \%$ approved of the government's tactics. ${ }^{53}$ As the poll and media survey suggests, the press and their readers remained divided over the legitimacy of the Royal Commission on Espionage.

While editors and politicians debated the question of how to best protect Canadians' civil liberties, several organizations throughout Canada were active in lobbying the federal government to develop greater safeguards against state abuse of individual rights. The history of civil liberties' groups in Canada is fragmented and few historians have chosen to document the activities of these groups in detail. According to Larry Hannant, modern "civil liberties associations focus on political rights considered universal within liberal democratic societies: freedom of speech, association, and worship, the right to a fair and impartial trial, and equality before the law, among others." ${ }^{44}$ A national civil liberties association did not exist in Canada until 1963; the early civil liberties movement was limited to small groups located in the metropolitan areas of Montreal, Toronto, Ottawa, Vancouver and Winnipeg. At a time when the Left in Canada was bitterly divided between communists and social democrats, the movement to organize interest groups dedicated to defending individual rights would find itself at times paralyzed by these ideological divisions. The reaction from civil liberties groups to the Gouzenko affair reflected the problems caused by these antagonisms, but the government's actions were extreme enough to provide these organizations with the issue they needed to promote public debate and awareness over the vulnerability of Canadians' civil liberties.

The earliest civil liberties groups in Canada included minority ethnic and religious groups, as well as organized labour. The Communist Party of Canada (CPC) played a key role in the creation of civil liberties groups before 1939,55 such as the Canadian Labour Defense League (CLDL) in 1925, an organization dedicated to providing financial and legal support to workers "prosecuted for expressions of opinion or for working class activity." active during the 1930s and early 1940s but limited its efforts to defending "only workers and those on the political left; it did not pretend to follow the dictum of making no distinctions about whose liberties it defended." 57 The creation of Vancouver and Montreal branches of the Canadian Civil Liberties Union 
(CCLU) in the late 1930s signaled a step closer to the creation of a contemporary civil liberties organization as described by Hannant (both groups included social democrats and communists among their membership). Branches of the CCLU emerged in Ottawa (1939) and Winnipeg (1938) as well, but both groups died during the war; a Toronto branch of the CCLU was created in 1938 but renamed itself the Civil Liberties Association of Toronto (CLAT) in $1940 .{ }^{58}$ The Montreal branch of the CCLU failed to emerge intact and active after the Second World War. In his history of the Montreal branch of the CCLU, Lucie Laurin argues that the repressive tactics employed by the state during the war through the Padlock Act and the Defence of Canada Regulations strangled the organization. ${ }^{59}$ More recently, however, Hannant has argued that the leader of the Montreal branch, R.A.C. Ballantyne, admitted in a letter to a colleague in the CPC (Frank Park) that the executive suspended the branch's operations as part of the CPC's decision to throw support behind the government to fight the war. ${ }^{60}$ For Canadian communists, the war had taken precedence over individual rights.

Despite the existence of communists and social democrats within these organizations, the Left was never able to work together on a national scale to promote greater legal protections for individual rights. While CCF'ers viewed "themselves as honest defenders of civil liberties who were generally appalled by the prosecution of the communists, they nevertheless were deeply suspicious of all communist activity... officially the founding fathers of the CCF decided to have nothing to do with the CPC or any of its front organizations such as the CLDL." ${ }^{61}$ Equally, by the Second World War the CPC "saw the CCF as their historic foe and rival for the leadership of the working-class." 62 These divisions inevitably had an effect on the early civil liberties movement. Liberal and social democrats were driven out of the Montreal branch of the CCLU in 1940-1; the Civil Liberties Association of Winnipeg refused to allow communists to join its ranks; conflicts between communists and social democrats heated up in the ranks of the Civil Liberties Association of Toronto when the former attempted to take over the executive; and the Vancouver branch of the CCLU was led by a dedicated social democrat, George G. Sedgewick. ${ }^{63}$

By 1945 , the Canadian civil liberties movement had undergone a significant ideological transformation; whereas communists and the CPC had taken the lead in organizing civil liberties groups up to 1939 , social democrats and liberals where now in charge. One of the key reasons for this development was the ban on communist organizations by the federal government in 1940 which led to the elimination of the CPC and the CLDL. Hannant has suggested that "the impact of the ban was two-fold... it opened a vacuum in the field of civil liberties, which could be filled by social democrats... it made communism more than just a heretical political movement; now it was an illegal one... barring communists from civil liberties organizations would henceforth be much easier." ${ }^{64}$ It is possible that government propaganda and the experience of the war had the effect of labeling civil liberties groups as communist fronts, although the lack of 
opinion polls makes such a determination difficult. There is no doubt that the RCMP considered most of these organizations as fronts for the CPC. ${ }^{65}$ As a writer for the Canadian Forum suggested in 1946, "because civil liberties have mistakenly and vaguely become identified with the Left in the public mind, those of conservative outlook have become increasingly insensitive to the need for their protection." 66

Only three groups emerged from the war intact: the Civil Liberties Association of Toronto (CLAT), the Civil Liberties Association of Winnipeg (CLAW) and the Vancouver Branch of the CCLU. Key members of the CLAT such as B.K. Sandwell, editor of Saturday Night, and Arthur Lower, a professor at the University of Manitoba, in the CLAW were liberals while the Vancouver branch of the CCLU was led by George Sedgewick, a social democrat with liberal leanings who "would never have supported a communist-dominated organization."67 The membership of these groups consisted mainly of journalists, politicians, academics, lawyers, and church ministers.

It was, therefore, a young civil liberties movement suffering from ideological divisions that confronted the Liberal government and the Royal Commission on Espionage in 1946. The movement would receive an important stimulus as a result of widespread criticism against the decision to hold people for several weeks without charge and lacking access to family or counsel. The reaction to the commission also provides a good example of the obstacles that civil libertarians needed to overcome in order to form an organized and national civil liberties movement.

The most notable impact of the Gouzenko affair on the civil liberties movement was the creation of two new organizations, one in Ottawa and the other in Toronto. The Ottawa Civil Liberties Association (OCLA) elected Wilfrid Eggleston as its first president and the group's founding members included such well-known figures as Senators Arthur Roebuck and Cairine Wilson. Unlike similar organizations in Winnipeg and Toronto, the Ottawa group did not exclude communists but instead attempted to bridge the ideological gap that had previously plagued the movement. In a recent dissertation, Ross Lambertson contends that the OCLA appeared "to have been one of the last attempts to create a civil liberties organization which spanned the increasing ideological gulf between the far left and those further to the right." 68 On the other hand, the Emergency Committee for Civil Rights (Toronto), led by a rich divorcee named Margaret Spaulding, appears to have been a communist dominated organization. ${ }^{69}$ The creation of the ECCR signaled a clear break from the more conservative CLAT, although on at least two occasions the two groups were able to overcome their ideological differences and work together. On 28 November 1946, groups from Montreal, Ottawa and the two Toronto organizations met together in an exploratory conference to discuss current issues such as Quebec's Padlock Act and federal censorship regulations. ${ }^{70}$ Later, in 1947, they met again to organize a civil rights rally in Toronto that included 
such speakers as Senator Roebuck and Leslie Roberts of the Montreal Civil Liberties Association. ${ }^{71}$ Both meetings appear to have been uncommon examples of cooperation between social democrats and communists. As an analysis of the reaction by civil libertarians to the Gouzenko affair demonstrates, the divisions between social democrats and communists would have a direct impact on the ability of civil liberties groups to attack the government on its tactics in dealing with the spy ring.

The Montreal Civil Liberties Association (MCLA) was the third such organization to emerge in 1946; unlike the OCLA and the ECCR, the MCLA did not emerge in direct reaction to the Royal Commission on Espionage (although it no doubt had an impact). The MCLA, led by Frank Scott, did not participate in the debate over the commission outside of publishing a newspaper advertisement condemning PC $6444 .{ }^{72}$

By November 1946, there were six active civil liberties organizations across Canada: the Vancouver branch of the CCLU, CLAT (Toronto), CLAW (Winnipeg), MCLA (Montreal), OCLA (Ottawa) and the ECCR (Toronto). Most of them openly advocated the creation of a Canadian Bill of Rights. When representatives from the Ottawa, Montreal and Toronto associations met to discuss common strategies in December, 1946, they all expressed a desire to create a constitutionally entrenched Bill of Rights. ${ }^{73}$ Between 1944-8, these groups attempted to gain public support by publishing advertisements in newspapers and writing letters to Members of Parliament demanding an entrenched Bill of Rights. ${ }^{74}$ The Winnipeg and Vancouver groups were unrepresented in the meeting, but they were active in promoting this cause to the Canadian people in local newspapers and, in the case of Arthur Lower in Winnipeg, publishing a booklet on civil liberties for the Canadian Historical Association. ${ }^{75}$ In promoting a Bill of Rights, these organizations commonly referred to the internment of Japanese Canadians, the mistreatment of Jehovah's Witnesses in Quebec, censorship during the war, the Royal Commission on Espionage, racial discrimination and the Padlock law in Quebec. The desire for a Canadian Bill of Rights was best stated in the following passage taken from a pamphlet published by the Winnipeg Civil Liberties Association in 1946:

Recent events in Canada and throughout the world have demonstrated that it is desirable that such rights be stated with the utmost clarity in the written Constitution of Canada, namely the BNA Act, in order that all men and women in Canada shall know them and shall feel that their rights are secure from interference by legislative or administrative action, through the protection of the Court. ${ }^{76}$

The effectiveness of these organizations in protecting civil liberties and lobbying for a Bill of Rights is difficult to gauge. Their members were active in promoting the cause of freedom throughout the press. Frank Scott published extensively in the Canadian Forum, B.K. Sandwell supported greater legal 
protections for individual rights in Saturday Night, and the Winnipeg Free Press made its editorial pages available to Arthur Lower of the Winnipeg Civil Liberties Association. They also produced pamphlets and organized conferences to spread ideas and attract public attention. While the demographics of their membership suggested little more than a group of intellectual elites, these organizations would emerge from the war intact, organized and prepared to confront the government on any abuse of individual rights.

The release of the commission's remaining detainees on 29 March 1946, was followed by the completion of the commission's final report on 26 June, 1946. With so much focus on the issue of civil liberties in the press, it is not surprising that the commissioners used the final report to defend the tactics employed during their investigation. Responding to the accusation that the commission circumvented the witnesses' right against self-incrimination by pressuring them into testifying, Taschereau and Kellock argued that the right to remain silent was based on the belief that fear and coercion should not motivate confessions. ${ }^{77}$ Although holding suspects without access to lawyers and family for over five weeks was certainly suggestive of fear and coercive tactics, the commissioners defended their position by quoting statute law. In this case, the Canada Evidence Act, was designed to protect witnesses from having their testimony used against them in court, but it was only applicable to individuals accused of a crime. The commissioners claimed they never charged anyone with a crime, but were simply conducting an inquiry. Hence, they did not have to inform people of this particular Act. They concluded that "in not warning the witnesses, we have then followed the only legal course open to us."78

The civil liberties groups operating at this time were not convinced by the arguments of the two Supreme Court justices. The files of the Department of Justice and External Affairs offer a rich source of documentation on the Royal Commission on Espionage, including correspondence from various civil liberties organizations. These files include resolutions passed by the Ottawa Civil Liberties Association and the Manitoba Civil Liberties Association (formerly CLAW) in July, 1946, condemning the distribution of the commission's final report because it could prejudice upcoming trials. The report commented extensively on the character of each suspect and suggested they were predominantly motivated by an ideological belief in communism to betray their country. The commissioners were determined to discern what motivated the suspects to spy and the report detailed every aspect of their political beliefs. Instead of simply describing the activities of each individual witness, however, the commissioners chose to write a chapter on each suspect, at the end of which they concluded that each person was "guilty of violating the Official Secrets Act." This led both civil liberties organizations to argue that the government, in distributing the report as an official document, legitimized the accusations of guilt contained in the report despite the fact that they had no legal substance (Royal Commissions can not convict criminals). ${ }^{79}$ 
Attempts by civil liberties groups to condemn the government's tactics were likely hampered by the fact that the suspects were perceived as communist sympathizers. Anti-communist sentiment was popular in Canada after WWII. According to historians Margaret Conrad and Alvin Finkel, "communists and ex-communists faced constant surveillance and harassment." 80 In the case of labour unions, Finkel and Conrad argue that "communist sympathizers who had been democratically chosen to head unions were denounced so stridently in the media and by their non-communist union opponents that the state confidently persecuted them and, in some cases, destroyed their union." ${ }^{\text {"81 }}$ It is no surprise, therefore, that many civil liberties associations openly shunned communist membership. Two journals, Saturday Night and Canadian Forum, were critical of civil liberties abuses by the state during the war and both editors, B.K. Sandwell (Saturday Night) and Eleanor Godfrey (Canadian Forum), were active members of civil liberties groups. Both journals had become a forum for members of various civil liberties associations, including F.R. Scott, F.H. Underhill and A.R.M. Lower, lawyers such as J.L. Cohen and R.M. Chitty, and a future member of the United Nations Human Rights division, J. King Gordon. Most of these people considered themselves social democrats or liberals and eschewed communism. This ideological division created an interesting problem for civil libertarians who found themselves defending the rights of communists accused of spying for the Soviet Union.

A quick analysis of both journals' coverage of the Gouzenko affair suggests that the suspects' communist affiliations affected the reaction from civil libertarians to the Royal Commission on Espionage. Between April, 1946, and March 1948, only four articles on the espionage affair appeared in the Canadian Forum. Two of the articles focussed on defending the accused's ideological beliefs instead of criticising the commission's tactics. Conversely, in the other two articles, the authors focussed on denouncing the use of preventative detention as a form of administrative (bureaucratic) over judicial internment. ${ }^{82}$ These pieces represented the Canadian Forum's entire coverage of Gouzenko's defection and the commission. For a periodical that consistently defended civil liberties during the war, the Canadian Forum gave surprisingly little attention to the government's most extensive abuse of individual rights in the post-war period. Saturday Night, a weekly periodical as distinct from a monthly like the Canadian Forum, provided more coverage of the commission. Between February, 1946, and March, 1948, there were seven stories that dealt with the espionage affair. The two most prominent civil libertarians writing for Saturday Night were B.K. Sandwell, the editor and member of the Toronto Civil Liberties Association, and Wilfrid Eggleston, a member of the Ottawa Civil Liberties Association. Both writers expressed instant opposition to the commission's approach. They were especially critical of the secrecy surrounding the investigation, the lack of counsel and the use of judges on a Royal Commission investigating a crime. Sandwell and Eggleston's comments in Saturday Night 
demonstrated the dichotomy between a desire to avoid the perception that they were sympathetic to communists, while simultaneously condemning the government's tactics. Eggleston's views were summarized in the following passage:

had any government failed to move swiftly and courageously in any matter which it sincerely believed threatened the security of Canada... it would have been far more reprehensible if it erred on the other side... [but] surely the security of the state against foreign espionage can be established and maintained by means which do not strike such a blow at the traditional liberties of the individual. ${ }^{83}$

Eggleston and Sandwell sought to criticize the government's tactics while applauding its hard stance against communism. It is also interesting to note that many of the central figures of the civil liberties movement at this time, among them Frank Scott and Frank Underhill, rarely commented on the espionage affair, preferring instead to attack the federal government's decision to intern Japanese Canadians. ${ }^{84}$

It is difficult to avoid the conclusion that the suspects' communist affiliations forced many of Canada's leading civil libertarians to moderate their attack on the Royal Commission on Espionage. The division between communists and social democrats created several problems in uniting the movement and hampered the attempts of civil liberties groups which may have been perceived by the general public as communist fronts. It had only been four years prior to the commission's creation (1942) when B.K. Sandwell and other members of the Toronto Civil Liberties Association barely managed to fight off an attempt by several communist members to gain control over the association's executive board. ${ }^{85}$ Several other civil liberties organizations also suffered from internal divisions between communists and non-communists. The Ottawa Civil Liberties Association, newly formed in response to the commission's proceedings, was no less vulnerable to internal disputes. Tensions mounted at the organisation's 1947 general meeting when a battle ensued over the appointment of a new president for the Association. Members left the meeting divided after the group's communist supporters failed to gain a majority of the seats in the executive council. ${ }^{86}$ These divisions may account for the fact that Canada lacked a national civil liberties association until 1963 with the creation of the Canadian Civil Liberties Association. The result was a tense dividing line in which the government's abuse of individual rights was viewed as deplorable, but its rooting out of subversive communists was seen as commendable.

Divisions within the Canadian civil liberties movement were mirrored south of the border. The American Civil Liberties Union (ACLU) was founded in 1919 to defend conscientious objectors to World War One, and soon emerged as one of the nation's leading defenders of individual rights. But the ACLU was no less vulnerable to the ideological divisions encouraged by anti-communist 
hysteria. Samuel Walker notes the dilemma which the ACLU faced with the birth of the cold war:

The ACLU entered the cold war deeply divided... [anti-Communist liberals] were more determined than ever to keep the ACLU free of any taint of Communism, which meant not opposing most of the cold war measures... On the other side in the ACLU stood a group of First Amendment absolutists... They opposed on principle all restrictions based on political beliefs and associations. ${ }^{87}$

The ACLU was no stranger to defending unpopular people from abuse of their First Amendment rights; the organization was born amidst controversy over their support of people's right to oppose the war. When it came to communists, however, the ACLU was as hesitant as its Canadian counterparts in speaking out against the state's suppression of communist groups. Walker contends that the organization's greatest failure during the cold war was to turn a blind eye the FBI's excessive tactics in rooting out subversives. "Between 1947 and 1954," he argues, "a cold war also raged inside the ACLU as the three factions struggled for the soul of the organization. Torn by its internal disputes, the ACLU at times appeared hesitant during the cold war." 88

One of the most notable similarities between the American and Canadian experiences as a result of this ideological divide was the creation of new civil liberties groups frustrated with the intransigence of established organizations. The Emergency Civil Liberties Committee emerged five years following its Canadian cousin, the Emergency Committee for Civil Rights; both groups focused on defending those communists that the ACLU or CLAT were unwilling to aide. ${ }^{89}$ No evidence is available to suggest any collusion between the two organizations, and neither was able to develop into a national group or survive beyond the cold war.

Despite these divisions, civil liberties organizations in Canada managed to play an important role in increasing public awareness through newspaper articles, pamphlets, and letters to Members of Parliament. As mentioned earlier, the commission's investigation resulted in the creation of two more civil liberties associations and the formation of the MCLA would bring total number of civil liberties groups to six by November, 1946. All six groups, some with greater vigour that others, contributed to spreading awareness about the abuses committed by the commission. Members of the Winnipeg Civil Liberties Association (CLAW) wrote articles for the Winnipeg Free Press and, as mentioned earlier, A.R.M. Lower produced a booklet for the Canadian Historical Association. ${ }^{90}$ The 27 January, 1947 rally organized by the ECCR and the Toronto Civil Liberties Association (CLAT) including a scathing attack by Senator Arthur Roebuck on the commission's exploits in the previous year. ${ }^{91}$ The Montreal Civil Liberties Association was represented at the rally by Leslie Roberts and published a critique of PC 6444 in the Montreal Star. ${ }^{92}$ The 
Vancouver CCLU, the CLAW and the OCLA passed resolutions condemning the commission and the latter two circulated copies to Members of Parliament and the Senate. ${ }^{93}$ The ECCR was responsible for several advertisements in the Toronto Star criticizing the commission for deviating from established principles of British justice. ${ }^{94}$ By the end of 1946, each organization and their individual members had thrown themselves into the task of condemning the Royal Commission on Espionage.

The Emergency Committee for Civil Rights (changed to the Civil Rights Union in 1947) was one of the two groups which conducted the most research on the commission; the other was the Ottawa Civil Liberties Association. ${ }^{95}$ The former authored a lengthy memorandum entitled, "Justice and Justice Only?" (Toronto report); the latter established a fact-finding committee in April, 1946, which produced a comprehensive report on every aspect of the government's investigation (Ottawa report). ${ }^{96}$ Most of the criticisms mentioned earlier, including issues of self-incrimination, access to counsel and the use of the War Measures Act were dealt with in these reports. Both provide an excellent insight into the circumstances surrounding the commission's investigation. The Ottawa report includes dozens of interviews with lawyers, people questioned before the commission, the suspects' spouses, politicians and journalists. It offers several examples of how the Royal Commission on Espionage stimulated paranoia towards alleged communist subversives as a result of their findings. In one instance, RCMP guards at the Rockliffe barracks refused to allow one of the suspect's wives to provide her husband with a book entitled The Spirit of Democracy. ${ }^{97}$ There are also accounts of RCMP officers tearing up letters from family members and suspects alleging to have been psychologically tortured by the commission. The report provides several examples of how the commission's proceedings prejudiced upcoming trials. In one instance, a bank teller claimed to have seen a spy in the bank; the "spy" was one of the suspects who had just been released by the commission and was free on bail, having not yet been tried in court. ${ }^{98}$ The Toronto group's report was similarly extensive in its analysis and offers examples of press commentary and an analysis of the War Measures Act, Official Secrets Act and the Inquiries Act. Their memorandum examines every aspect of the commission's final report to demonstrate how extensively character judgment and the suspects' ideological beliefs influenced the commission's conclusions (in the cases of Matt Nightingale and J.S. Benning, character judgment was the sole basis for the commission's accusation of guilt). Each report is remarkable in its attention to detail and the amount of time and effort it must have taken to complete.

The ability of civil liberties groups and the press to conduct a detailed examination into the government's activities demonstrates that the civil liberties movement was well-organized by 1946 . Civil libertarians were capable of mobilizing their resources to produce detailed and accurate analyses of the commission's activities. The Ottawa and Toronto reports were created within a 
few months following the initial arrests, indicating how quickly these groups were able to act. Their research was then passed on to the public through articles in various journals, pamphlets, newspaper advertisement, and speeches at rallies and in the House of Commons. Despite growing anti-communist sentiment in Canada at this time, it is clear that the Royal Commission on Espionage played an important role in stimulating awareness of civil liberties issues in Canada.

The momentum of the post-war period, however, did not last very long. Despite the important victories achieved by Frank Scott and others in the courtroom during the $1950 \mathrm{~s}$, most of the civil liberties groups that had been active in 1946 were moribund within a few years. The Vancouver branch of the CCLU, the Ottawa Civil Liberties Association, the Montreal Civil Liberties Association and the Winnipeg/Manitoba Civil Liberties Association had all disappeared by 1951 . Two additional groups, the University of British Columbia branch of the CCLU and the McGill University Civil Liberties League emerged in 1947-8 but soon became defunct. ${ }^{99}$ The only two organizations to remain active in the 1950s included the League for Democratic Rights which was formed in 1950 when the Civil Rights Union (formerly the ECCR) and the recently formed Montreal Civil Liberties Union joined forces to create a national civil liberties organization. The Association for Civil Liberties was created in 1949 by members of the CLAT with similar hopes of creating a national civil liberties association. The two groups symbolized the continuing divisions between communists and social democrats in the civil liberties movement, and neither group remained active by the late 1950s.

There are a variety of reasons why none of the organizations that were active in the 1940s survived into the next decade. Divisions between social democrats and communists as well as the pressures of the cold war no doubt had an impact in limiting expansion of these organizations. ${ }^{100}$ The most likely reason, however, has been put forth by Ross Lambertson is a recent $\mathrm{PhD}$ dissertation. According to Lambertson, the civil libertarian impulse simply waned in the late 1950s. After 1956, however, the threat of communism subsided. Racism and prejudice remained significant threats to democratic equality, but these were the focus of egalitarian rights groups, and although the civil liberties organizations had begun to lend their aide to this cause, even during the war, they seldom played more than a supporting role. ${ }^{101}$

By the 1950s, the most active defenders of civil liberties would therefore not be one of the many civil liberties associations to emerge in the post-war period, but such groups as the Canadian Jewish Congress (CJC) or the Canadian Congress of Labour (CCL). Both the CJC and the CCL would play an important role in the creation of anti-discrimination legislation in the 1950s.

The Royal Commission on Espionage thus took place during the initial stages of a civil liberties movement, later symbolized by Canada's signing of the United Nations Declaration of Human Rights in 1948. While the Liberals never acceded to any of the major demands for reform, such as creating a Bill of Rights 
for Canada, they implemented a Joint Parliamentary Committee on Human Rights and Fundamental Freedoms in 1947 and 1948. A Senate committee was also formed in 1950 to examine the possibility of a Canadian Bill of Rights and it was led by one of the commission's most prominent critics, Senator Roebuck. This committee played an important role in informing the debate over the creation of a Bill of Rights throughout the 1950's which, ironically, would be created by the Conservatives under John Diefenbaker.

In reference to the Royal Commission's investigation, an American writer for the Washington Post suggested in 1946 that the issue was "not merely whether governments, when they profess to be no longer able to trust their own employees, should be given extra constitutional powers of search, seizure, also imprisonment, but whether we dare, even for the sake of keeping our secrets, trust any government with such powers." 102 The Royal Commission on Espionage epitomized everything democracies fear of governments with too much power. The commission overrode a police investigation and generally acted as an independent judicial system by ignoring traditional liberties including the right to engage counsel, to know one's charges, and a host of others. Nonetheless, the late 1940s was a coming of age for Canada. The reaction from the media, legal profession and civil liberties groups demonstrated an increasingly popular belief in fundamental liberties that were inviolable. This movement was the precursor of significant changes about to emerge in Canadian jurisprudence, as seen in the decisions of the Supreme Court in the 1950s and the introduction of a Bill of Rights in 1960. Radical change tends to come slowly in Canada; the enshrinement of the principles advocated by many in the post-WWII civil liberties movement did not become a constitutional reality until the 1982 Charter of Rights and Freedoms. With the benefit of hindsight we can claim that the Royal Commission on Espionage's historical significance was to bring more attention to the dangers inherent in a society with no defence against state abuse of civil liberties. ${ }^{103}$

${ }^{1}$ Special thanks are extended to Gregory Kealey at Memorial University and George Egerton at the University of British Columbia who supervised the production of this work, and to Tara Roy-DiClimente for her excellent editing skills. Reg Whitaker and Ross Lambertson also provided invaluable feedback on the final draft.

${ }^{2}$ National Archives of Canada [hereafter: NAC], Louis St. Laurent Papers, v.19, f. 100-9, Civil Rights Union to Justice Minister Ilsley, 15 February, 1947.

${ }^{3}$ The commission's official name was the Royal Commission to Investigate Facts Relating to and the Circumstances Surrounding the Communication, by Public Officials and Other Persons in Positions of Trust of Secret and Confidential Information to Agents of a Foreign Power. The commission is most commonly referred to as the Royal Commission on Espionage.

${ }^{4}$ Canada, Statutes of Canada, An Act To Confer Certain Emergency Powers 
Upon the Governor in Council, R.S. 1952, c. 93; Canada, Statutes of Canada, An Act Respecting Official Secrets, R.S.C. 1939, c.49; Canada, Statutes of Canada, An Act Respecting Public and Departmental Inquiries, R.S. 1906, c. 104.

${ }^{5}$ In this particular context, the term "civil liberties" refers to specific rights. After WWII, both Canadian and American statesmen were primarily concerned with political and civil rights instead of economic and social rights. In this case, the commission questioned those legal rights (under common law) designed to protect people from police harassment and to ensure individuals' access to a fair trial. These included the right to legal counsel, the right to remain silent and the right to be brought before a magistrate within a reasonable length of time (habeas corpus). The other terms often used in rights discourse are "civil rights" and "human rights." These terms are problematic because the former is included in the British North America Act (under Section 92 of the BNA, "Property and Civil Rights" are placed under provincial jurisdiction) and there is some debate as to its true meaning; the latter is a term popularized after the commission completed its investigation. The term "civil liberties" appears to provide both clarity and consistency.

${ }^{6}$ J.W. Pickersgill and D.F. Foster, The Mackenzie King Record, Vol. 3: 1945-6, (Toronto 1970)

${ }^{7}$ Canada, 1946, Royal Commission to Investigate Facts Relating to and the Circumstances Surrounding the Communication, by Public Officials and Other Persons in Positions of Trust of Secret and Confidential Information to Agents of a Foreign Power, [hereafter: Report], 649.

${ }^{8}$ Report, 649.

${ }^{9}$ For more information on Gouzenko's time at Camp X see: David Stafford, Camp X, (Toronto 1986).

${ }^{10}$ Pickersgill and Forster, 135.

${ }^{11}$ Evening Citizen, 16 February, 1946.

${ }^{12} \mathrm{~A}$ copy of the oath taken by RCMP officers guarding the prisoners is available at: http://www.rcespionage.com/oath.htm.

13 The lack of a stenographer meant that no records survived of these interrogations. However, the proceedings are described by Harvison in his biography as well as the life stories of two of the suspects, including a biography of Emma Woikin and Gordon Lunan's autobiography. See: June Callwood, Emma, (Toronto 1988); C.W. Harvison, The Horsemen, (Toronto 1967); Gordon Lunan, The Making of a Spy, (Toronto 1995).

${ }^{14}$ The commission's final report provides an entire section on the law and procedures taken by the commission. See: Report, 649-684.

${ }^{15}$ Details on the treatment of the suspects may be found in: Callwood, Emma; Harvison, The Horsemen; Ross Lambertson, Activists in the Age of Rights: The Struggle for Human Rights in Canada, 1945-60, (PhD diss., University of Victoria, 2000); Lunan, The Making of a Spy; Gary Marcuse and Reg Whitaker, Cold War Canada: The Making of a National Insecurity State: 1945-1957, 
(Toronto 1994).

${ }^{16}$ Canada, Statutes of Canada, An Act Respecting Public and Departmental

Inquiries, R.S. 1906, c.104,s.4.

${ }^{17}$ Ibid.

${ }^{18}$ Section 5 of the Canada Evidence Act states that a witness' testimony before a court or government tribunal may not be used against them in court if they specifically request and are granted protection under the Act by the presiding magistrate. See: Canada, Statutes of Canada, An Act Respecting Witnesses and Evidence, R.S. 1927, c. 59.

${ }^{19}$ These were some of the code names assigned by the Russians for their spies. See NAC, Records of the Department of Justice, RG 13, Vol.2119, 2121.

20 Top-secret memorandum from E.K. Williams to Mackenzie King on 5 December, 1945, in Ibid.

${ }^{21}$ Excerpts from the commission's report and suspect's testimony are available at: http://www.rcespionage.com/report.htm.

22 NAC, J. King Gordon Papers, v.19, f.15, "Report of a Fact-Finding Committee," report produced by the Ottawa Civil Liberties Association, [hereafter: OCLA Report], 4.

23 OCLA Report, 5.

${ }^{24}$ lbid.

${ }^{25}$ Ibid.

${ }^{26}$ James Chalmers McRuer of the Ontario High Court was the first judge to preside over one of the spy trials. He covered four of the espionage trials and established several precedents on the admissibility of evidence, including allowing the use of the commission's transcripts. McRuer was later appointed to the Ontario Court of Appeals as Chief Justice and, ironically, chaired the Royal Commission on Civil Rights (1967) in Ontario that was responsible for major revisions to provincial statutes to ensure greater protections for civil liberties. Among the 1967 commission's many recommendations was an amendment to the Ontario Inquiries Act to guarantee counsel for any witness brought before a government tribunal. He was also one of the founders of the Civil Liberties Association of Toronto alongside one of the commission's legal counsels, Andrew Brewin. For further details on McRuer's life refer to: Patrick Boyer, $A$ Passion for Justice, (Toronto 1994).

${ }^{27}$ Section 3 (1) of the Official Secrets Act states the following as the basis for determining someone guilty of violating the Act: "If any person for any purpose prejudicial to the safety or interest of the State, approaches, inspects, passes over, or is in the neighborhood of, or enters any prohibited place; he shall be guilty of an offence under this Act." The language is broad enough that someone could be found guilty if they were caught at the same cocktail party with another person convicted of spying against the state. See: Canada, Statutes of Canada, An Act Respecting Official Secrets, R.S.C. 1939, c

${ }^{28}$ Frederick W. Gibson, Queen's University, Vol 2, (1917-1961), (Kingston 
1983), 281-2.

29 A more detailed narrative on the events of $1946-9$ is available at: $\mathrm{http}: / /$ www.rcespionage.com/A_Brief_History.htm.

30 Emma Woikin, Kathleen Willisher, Gordon Lunan, Edward Mazerall, Raymond Boyer, Harold S. Gerson, and Durnford Smith were all convicted. Matt S. Nightingale, David Shugar, Eric Adams, J.S. Benning, Israel Halperin, Fred Poland and Agatha Chapman were acquitted in court. Frada Linton and S.S. Burman were also accused of violating the Official Secrets Act by the commission, but lack of evidence made it impossible to charge them with the offence.

${ }^{31}$ Marcuse and Whitaker, Cold War Canada.

32 Ibid., 269.

${ }^{33}$ Larry Hannant, The Infernal Machine: Investigating the Loyalty of Canada's Citizens, (Toronto 1995), 253.

34 Winnipeg Free Press, 11 March, 1946.

${ }^{35}$ Ibid.

${ }^{36}$ Saturday Night, 6 April, 1946, 10.

37 Vancouver Sun, 19 March, 1946.

${ }^{38}$ Globe and Mail, 6 March, 1946.

${ }^{39}$ Montreal Gazette, 16 March, 1946.

${ }^{40}$ Halifax Herald, 21 February, 1946; 1 March, 1946; 5 March, 1946; 11 March, 1946; 16 March, 1946; 21 March 1946; 1 April, 1946; 2 April, 1946; 3 April, 1946; 4 April, 1946; 5 April, 1946; 11 April, 1946 and 15 April, 1946.

${ }^{41}$ Averages are determined as follows: Evening Citizen (Ottawa), 47 stories; Globe and Mail (Toronto), 44 stories; Vancouver Sun, 44 stories; Winnipeg Free Press, 42 stories; Halifax Herald, 43 stories; Montreal Gazette, 43 stories. 263 stories divided by 6 papers totals 44 . As a result, each paper produced fortyseven newspapers between 16 February, 1946-16 April, 1946 and a story on the commission appeared, on average, in forty-four of these papers.

42 The only person writing for Action Catholique who chose to comment editorially on the espionage affair was George-Henri Dangneau. He suggested that the following lesson could be learned from the events surrounding the disclosure of top-secret information by civil servants in Ottawa: "on peut tout de même constater que justqu'ici aucun compatriote de notre langue n'est tombé dans les filets de l'attaché militaire russe... pourquoi, à Ottawa, s'acharne-t-on à laisser de coté des Canadiens français, qui ne parlent peut-être pas l'anglais avec l'accent d'Oxford ou de Cambridge, mais qui en plus d'avoir du talent, jouissent d'un equilibre moral et mental qui prévient toute espéce de compromissions, même en pensée? La leçon proftera-t-elle?" Action Catholique, 5 March, 1946.

${ }^{43}$ Norman Ward, ed., A Party Politician: The Memoirs of Chubby Power (Toronto 1966), 381.

${ }^{44}$ Toronto Daily Star, 30 July, 1946. Senator Roebuck, a Liberal appointee, was 


\section{Left History 7.2}

a well-known advocate for civil liberties by the late 1940s. In 1950, he chaired a Senate committee on human rights which dealt with controversial issues such as legal, religious, educational and language rights.

${ }^{45}$ NAC, Arthur Roebuck Papers, V.1, f. 15, "civil rights rally, guide for speakers," 27 January, 1947.

46. Canada. Hansard Parliamentary Debates, 1947, vol. 2, 1301.

${ }^{47}$ Ibid., 1947, vol.1, 55-7.

${ }^{48}$ Ibid., 1947, vol.2, 2364-6.

${ }^{49}$ Ibid., 1946, vol.1, 65-7.

50 Ibid., 1946, vol.1, 91.

51 Both Jean Lesage and Pinard opposed the motion to create a join parliamentary committee to consider a Canadian Bill of Rights. See Ibid., 1947, vol. 2,3117-3212.

52 Ibid., 1947, vol. 2, 3146.

${ }^{53}$ Toronto Daily Star, 16 April, 1946.

${ }^{54}$ Hannant, Infernal Machine, 220.

${ }^{55}$ Some of the groups formed in the 1930s that promoted civil liberties' issues and had social democratic/liberal leanings included the League for Social Reconstruction (1930-1942) and the Canadian Civil Liberties Protective Association (1933-6). Both organizations, as with their communist counterparts, had short life spans.

${ }^{56}$ The first aim of the CLDL, established during its national convention in 1927, read as follows: To provide legal defense for all workers prosecuted for expressions of opinion or for working class activity. Quoted in: J. Petryshyn, "Class Conflict and Civil Liberties: The Origins and Activities of the Canadian Labour Defense League, 1925-1940," Labour/Le Travail 10 (Autumn 1982): 39-63.

${ }^{57}$ Hannant, Infernal Machine, 222.

${ }^{58}$ For more information on the CCLU and its affiliates see: Lambertson, Activists in the Age of Rights, 302-5.

${ }^{59}$ Lucie Laurin, Des Luttes et des Droits: Antécédants et histoire de la Ligue des Droits de l'Homme, 1936 à 1975 (Montréal 1985), 35.

${ }^{60}$ Hannant, Infernal Machine 236-7.

${ }^{61}$ Petryshyn, "Class Conflict and Civil Liberties," 55.

${ }^{62}$ Norman Penner, The Canadian Left: A Critical Analysis (Scarborough 1977), 169.

${ }^{63}$ Records, although limited, are available on all seven civil liberties groups. Ramsay Cook provides an extensive analysis of the Winnipeg Civil Liberties Association (CLA) in his 1955 M.A. thesis: Ramsey Cook, "Canadian Liberalism in Wartime: A Study of the Defence of Canada Regulations and Some Canadian Attitude to Civil Liberties in Wartime." (MA Thesis: Queen's University, 1955). He refers to organizations in Toronto, Montreal and Vancouver; the latter two were members of the Canadian Civil Liberties Union 
(CCLU). There are also letters dated between 1945-9 from the Winnipeg C.L.A., Toronto C.L.U. and Toronto C.L.A. which are available in the Diefenbaker Papers (v.9, 10 and 82). The Montreal C.L.A. is on record as having made a presentation before the 1950 Senate Committee on Human Rights and Fundamental Freedoms (Roebuck commission).

${ }^{64}$ Hannant, Infernal Machine, 224.

${ }^{65}$ Lambertson, Activists in the Age of Rights, 40-2.

${ }^{66}$ Donald McDonald, "The Deepening Crisis in Civil Liberties," Canadian Forum 308 (June, 1946): 131.

${ }^{67}$ Lambertson, Activists in the Age of Rights, 45.

${ }^{68}$ Ibid., 172.

${ }^{69}$ NAC, Louis St. Laurent Papers, v. 19, f. 100-9, C.B. Macpherson to Minister of Justice Ilsley with ECCR letterhead, 15 February, 1947.

${ }^{70}$ NAC, J. King Gordon Papers, v. 19, f.15, agenda for meeting of civil liberties organizations, 28 December, 1946.

71 NAC, Arthur Roebuck Papers, v.1, f.15, speech and agenda for civil rights rally, 27 January, 1947.

${ }^{72}$ Montreal Star, 12 November, 1946.

${ }^{73}$ NAC, J. King Gordon Papers, v.19, f.15, agenda for meeting of civil liberties organizations, 28 December, 1946.

74 Correspondence and advertisements by various civil liberties groups available in: NAC, Louis St. Laurent Papers, v.9, v.99; NAC, John Diefenbaker Papers, v.9, 10; NAC, Records of the Privy Council Office, v.162, f. H-11.

${ }^{75}$ Material from the Winnipeg and Vancouver civil liberties groups available in: NAC, Arthur Roebuck Papers, v. 1, f.15; NAC, John Diefenbaker Papers, v.9, v.10. Ramsay Cook also provides a detailed examination of the Winnipeg Civil Liberties Association and the activities of Arthur Lower in: Cook, "Canadian Liberalism in Wartime."

${ }^{76}$ NAC, John Diefenbaker Papers, v. 9, pp. 6877-80, Winnipeg Civil Liberties Association to John Diefenbaker, (no date).

77 Report, 235.

${ }^{78}$ Report, 672-3.

${ }^{79}$ For correspondence by civil liberties groups to Parliament see: NAC, Records of the Department of External Affairs, v.2081, f. AR 13\13; NAC, Records of the Department of Justice, v.2119, v.2121; NAC, John Diefenbaker Papers, v.82, p.65442.

${ }^{80}$ Margaret Conrad and Alvin Finkel, History of the Canadian Peoples: 1867 to the Present $2^{\text {nd }}$ edition (Toronto 1998), 377.

${ }^{81}$ Ibid.

${ }^{82}$ Lester Phillips, "Preventative Detention in Canada," Canadian Forum (April, 1946); Donald MacDonald, "The Deepening Crisis."

${ }^{83}$ B.K. Sandwell, "Spying in Canada," Saturday Night 25 (23 February, 1946).

${ }^{84}$ Sandra Djwa, The Politics of Imagination: The Life of FR. Scott (Toronto 
1987), 235.

${ }^{85}$ Cook, "Canadian Liberalism in Wartime," 168-9.

${ }^{86}$ Lambertson, "Activists in the Age of Rights."

${ }^{87}$ Samuel Walker, In Defense of American Liberties (ACLU), (New York 1990), 175.

${ }^{88}$ The third group Walker refers to is the liberal centrists. Led by the ACLU's founder, Roger Baldwin, the held the balance of power and often sided with the anti-Communists. Walker, In Defense, 175-6.

${ }^{89}$ Ibid., 188.

90 NAC, Arthur Roebuck Papers, v.1, f.15, "Some Reflection on a Bill of Rights," copy of a booklet written by Arthur Lower for the Canadian Historical Association, (no date); NAC, John Diefenbaker Papers, v. 9, p.6857-81, "Two Ways of Life: The Spirit of Our Institutions," copy of article written by Arthur Lower for the Canadian Forum.

${ }^{91}$ NAC, Arthur Roebuck Papers, v.1, f. 15, copy of agenda for civil liberties rally in Toronto, 27 January, 1946.

${ }_{92}$ Montreal Star, 12 November, 1946.

93 NAC, John Diefenbaker Papers, v.9, p.6849, v.82, p.65438, resolution passed by the Winnipeg and Ottawa civil liberties associations (no dates). Files within the papers of Garnette Sedgewick indicate that, in several instances, the Vancouver branch of the CCLU passed resolutions condemning the commission, although it is unclear what action (if any) was taken by the organization. See: University of British Columbia Archives, personal papers series, 1893-1953, Garnette G. Sedgewick Fonds.

${ }^{94}$ NAC, John Diefenbaker Paper, v. 10, p.65434, v.82, p.65433, 65412., copies of advertisements published in the Toronto Daily Star by the Emergency Committee for Civil Rights (Toronto).

${ }^{95}$ Both organizations were formed in response to the commission's proceedings in 1946. The Ottawa group consisted of such influential figures as Senator Arthur Roebuck and Senator Carine Wilson, although neither was particularly active in the organization after its formation in March, 1946.

${ }^{96}$ NAC, Records of the Department of Finance, v.349, f. 101-85-24, "'Justice and Justice Only?' A draft memorandum on the fourth report of the KellockTaschereau commission," memorandum produced by the Emergency Committee for Civil Rights (Toronto), (ECCR Report); NAC, J. King Gordon Papers, v. 19, f.15, "Report of a Fact-Finding Committee," in OCLA Report.

97 The Report does not mention that the book in question, Spirit of Democracy, was written by Margaret Fairley, a member of the Communist Party of Canada. This may have influenced the RCMP's decision to keep the book out of the hands of the detainees who were, after all, suspected of being communist spies. OCLA Report, 3.

98 OCLA Report, 3-5.

${ }^{99}$ References to the formation of the UBC-CCLU and a copy of its constitution 
can be found in: University of British Columbia Archives, Alma Mater Society Archives, Box 19, "Constitution of the UBC-CCLU." 1948. On the top right hand corner of the constitution is handwritten note that states "presently inactive." For details on the formation of the McGill group see: Lambertson, Activists in the Age of Rights, 304.

${ }^{100}$ Lucie Laurin suggests that the replacement of Dupleissis' Union National with the Liberals created a better atmosphere for liberal activists to operate in Québec. Laurin, Des Luttes et des Droits, 57.

${ }^{101}$ Lambertson, Activists in the Age of Rights, 345.

${ }^{102}$ NAC, Records of the Department of External Affairs RG 25, G2, Vol. 26192620.

${ }^{103}$ Further information on the Royal Commission on Espionage is available at: www.rcespionage.com. For a complete bibliographical listing of sources used in researching this work, refer to: http://www.rcespionage.com/Sources.Main.htm. 